\title{
Ecological

\section{On the spider diversity of Salbardi forest and upper Wardha Dam Amravati India}

\section{Ujjwala Shivaji Deshmukh}

Assistant Professor, Department of Zoology Goverment Vidarbha Institute of Science and Humanities, Amravati. 444604 (M.S.), India

\begin{abstract}
Present study was carried out to explore the diversity and abundance of spiders from Salbardi Forest and catchment area of Upper Wardha Dam, Dist. Amravati, Maharashtra, India, for consecutive 2 year (2011-2013). The study areas were surveyed by making quadrants of approximately of $10 \times 10$ meters. The floor, undergrowth, rocks, firewood and stones were systematically searched for spiders. Each site was surveyed from early morning 8 AM to 6 PM at the interval of 7 days. During this survey 142 species of spiders from 62 genera of 21 families were recorded. The most diverse family observed was the Aranidae with 33 species followed by Salticidae 30, Oxyopidae and Thomisidae 11, Lycosidae 9, Gnaphosidae 8, Tertragnathedae 7, Philodromidae 4, Clubionidae, Erasidae, Pholcidae, Pisauridae, Theridiidae and Uloboridae 3 each, Hersilidae, Miturgidae, Scytodiidae and Sparassidae 2 each and Nephilidae, Sicariidae and Theridiosomatidae 1 species each. Abundance and diversity of spiders was recorded highest during August to December while least was recorded during summer. Amongst all families spiders from Salticidae were recorded throughout the year. However Lycosidae, Oxyopidae, Hersilidae and Thomisidae were predominantly observed during late monsoon and early winter. Seasonal variation showed a great impact on diversity and abundance of spiders. Their food consists of common insect pests; they are important predators in nature and may serve as bio-indicator species for specific ecosystem.
\end{abstract}

KEY WORDS: DIVERSITY, SPIDERS, UPPER WARDHA DAM, SALBARDI FOREST

\section{ARTICLE INFORMATION:}

Corresponding Authors: ujjwaladeshmukh@rediffmail.com Received $12^{\text {th }}$ July, 2018

Accepted after revision $21^{\text {st }}$ Nov, 2018

BBRC Print ISSN: 0974-6455

Online ISSN: 2321-4007 CODEN: USA BBRCBA

Thomson Reuters ISI ESC / Clarivate Analytics USA

Mono of Clarivate Analytics and Crossref Indexed Journal Mono of $C R$

NAAS Journal Score 2018: 4.31 SJIF 2017: 4.196

- A Society of Science and Nature Publication, Bhopal India 2018. All rights reserved.

Online Contents Available at: http//www.bbrc.in/

DOI: $10.21786 / \mathrm{bbrc} / 11.4 / 20$ 


\section{INTORDUCTION}

Spiders belong to phylum Arthropoda, class Arachnida, a large group of animals with jointed legs and rank seventh in total species diversity among all other group of organisms. Spiders are ancient animals with a history going back over 350 million years. They are abundant and widespread in almost all ecosystems and constitute one of the most important components of global biodiversity. The current global list of Spider fauna is approximately 42,055 belonging to 3821 genera and 110 families (Platnick, 2014). Although the fossils record of spiders is considered poor, almost 1000 spiders have been described from fossils. The oldest known amber that contains fossils arthropods dates from 130 million years ago in the early cretaceous period.

Spiders are generalist feeders with great species richness in every type of terrestrial habitat and play an important role in the structure of communities and food webs, both as an individual numbers and as energy consumers. Spiders acting as ecological indicator are cosmopolitan in distribution and locally abundant in terms of individuals and taxa. Their small body size allows them to maintain their community in small area. Spiders are insectivorous animal and insect fauna changes with the change in vegetation. Spiders play a significant ecological role by being exclusively predatory and thereby maintaining ecological equilibrium.

Spiders have a very significant role to play in ecology by being exclusively predatory and thereby maintaining ecological equilibrium. Bastawade (2004) described arachnid fauna of orders Araneae, Scorpionida and Solifugi from Melghat Tiger Reserve, Amravati, Maharashtra State. Spiders of protected areas in India are studied by Gajbe (1995a) in Indravati Tiger Reserve and recorded 13 species and Gajbe (1995b) 14 species from Kanha Tiger Reserve, Madhya Pradesh. Gajbe (2003) prepared a checklist of 186 species of spiders in 69 genera under 24 families distributed in Madhya Pradesh and Chhattisgarh. Patel (2003) described 91 species belonging to 53 genera from Parabikulum Wildlife Sanctuary, Kerala. Deshmukh and Raut (2014) reported 92 species from Salbardi forest, Satpura range Maharashtra. Manju Siliwal et al. (2003) recorded 116 species from 66 genera and 25 families of spiders from Purna wildlife Sanctuary, Dangs, Gujarat. Hippargi, et al. (2011 b) reported occurrence of spiders from 19, 25, 31 families from Lonar, Melghat and Southern Tropical Thorn forest, Solapur respectively. Hore and Uniyal (2008a, 2008b) worked on the spider assemblage and the diversity and composition of spider assemblages in different vegetation types in Terai Conservation Area (TCA). Hore and Uniyal (2008) worked on spiders as indicator species for monitoring of habitat condition in TCA. They also stud- ied on the effect of prescribed fire on spider assemblages in TCA. Sebastin and Peter (2009) studied spider fauna from irrigated rice ecosystem in central Kerala. Spiders provide vital control of the invertebrate population. They are skilled and efficient hunters of insects. Recent studies have investigated the importance of spiders as ecological indicators. Terrestrial arthropods, of which spiders are amongst, have long been monitored for early warning sign of environmental changes. The aim of this study was to investigate the spider species composition in different habitat type within Salbardi forest and Upper wardha Dam area.

\section{MATERIAL AND METHODS}

Study area: Present study was carried out to explore the diversity and abundance of spiders from Salbardi Forest (The Latitude and Longitude of salbardi is 21.4183 and 78.0113 respectively) and catchment area of Upper Wardha Dam (The Latitude and Longitude of Upper Wardha Dam is 21.2764 and 78.0572 respectively), Dist. Amravati, Maharashtra, India, (2011-2013). The study areas were surveyed by making quadrants of approximately of $10 \times 10$ meters. Salbardi is about $8 \mathrm{~km}$. (5 miles) North of Morshi, District Amravati, on the border lying partly in the Betul District of Madhya Pradesh on Madu River. Salbardi is named from its abundance of Sal trees and the stony character of its soil, Upper Wardha Dam is situated on Wardha River near to Morshi. Catchment area of both the sites comprises dry deciduous forest.

Field Methods: For adequate sampling the spiders from various spots were collected every weekend. The collection methods such as trapping, sweeping, beating, pitfall trap and visual search for webs or retreats were used. Only mature spiders were collected as well as repetition of collection was avoided. Collected spiders were identified using standard identification keys of Barrion and Litsinger (1995), Biswas and Biswas (2004), Gajbe (1999), Plantnick (1989), Tikader (1974, 1980, 1982 a and $b, 1987)$.

\section{RESULTS AND DISCUSSION}

Spiders were sampled from various habitats by making the quadrants approximately of $10 \times 10 \mathrm{~m}$. Consecutive two years survey result shows that total 142 species of spiders belonging to 61 genera and 21 families were identified. Table 1. Abundance and richness of spiders was at the peak during September to January. As spiders feeds exclusively on insects or other arthropods, which were abundantly found during the same season as seasonal flora is also at the peak. Among the specimen most of the individuals were females while very few number 


\begin{tabular}{|c|c|c|c|}
\hline Sr. No. & Family & $\begin{array}{l}\text { Number of } \\
\text { genera }\end{array}$ & $\begin{array}{l}\text { Number of } \\
\text { Species }\end{array}$ \\
\hline 1 & Araneidae & 08 & 33 \\
\hline 2 & Clubionidae & 01 & 03 \\
\hline 3 & Eeasidae & 01 & 03 \\
\hline 4 & Gnaphocidae & 05 & 08 \\
\hline 5 & Hersilidae & 01 & 02 \\
\hline 6 & Lycosidae & 03 & 09 \\
\hline 7 & Miturgidae & 01 & 02 \\
\hline 8 & Nephilidae & 01 & 01 \\
\hline 9 & Oxyopidae & 02 & 11 \\
\hline 10 & Philodromidae & 04 & 04 \\
\hline 11 & P Pholcidae & 02 & 03 \\
\hline 12 & Pisuiridae & 02 & 03 \\
\hline 13 & Salticidae & 14 & 30 \\
\hline 14 & Scytodidae & 01 & 02 \\
\hline 15 & Sicariidae & 01 & 01 \\
\hline 16 & Sparassidae & 01 & 02 \\
\hline 17 & Tetragnatidae & 02 & 07 \\
\hline 18 & Theridiidae & 03 & 03 \\
\hline 19 & Theriosomatidae & 01 & 01 \\
\hline 20 & Thomisidae & 06 & 11 \\
\hline \multirow[t]{2}{*}{21} & Uloboridae & 02 & 03 \\
\hline & Total & 62 & 142 \\
\hline
\end{tabular}

of males were observed. Chrysilla lauta is only male till now recorded from Saltisidae family was also observed during the survey.

Highest number of species were recorded from family Araneidae (33 species from 8 genera) or orb viewers, these spiders were found in all most all spots as well as in all seasons. Spiders from genus Neoscona was recorded with high abundance and most of them observed constructing their webs in the evening. Second diverse family was Saltisidae (30 species from 14genera) or jumping spider, spiders of which were recorded throughout the year and in all most all places. Only few species as Opisthoncus, Rhene, Siler, Telamonia were found during flowering season. Clubionidae (3 species from a single genus) commonly called as leaf rolling spider were observed through sacs in rolling leaves. Eresidae (3 species from a single genus) or Social spiders were observed through their typical web pattern unkempt irregular and large webs on trees, shrubs from height 4 feet to max 60 feet. In a single web numbers of spiderlings were found. Gnaphosidae (8 species from 5 genera), or ground spider were observed wondering on ground, under litters or in crevices. Hersilidae (2species from 1genus) or tailed spiders found on barks of trees, very much mimicking to habitat, spinnerets of these spiders are long just like tail. Lycosidae (9 species from 3 genera) or Wolf spider were recorded from ground and bushes. Miturgidae (2 species from 1genus) or Dark sac spider observed on vegetation mimicking to environment. Nephilidae (1 species from 1genus) or giant wood spiders, these were observed on huge webs constructed on large trees, with the average diameter of 8-10 meters. Female is large and rest at the centre while 3-4 males comparatively small, were found on web at the periphery. Oxyopidae or lynx spiders, these are colourful spiders observed abundantly during rainy season on seasonal flora, males of these were found in large number along with females. Philodromidae (4 species from 4 genera) or elongated crab spider or running crab spider are dull colored- brown, gray or yellowish spiders and do not build webs, but use silk for draglines and for egg sacs. These are observed running very fast on ground and grass. Pholcidae (3 species from 2 genera) commonly known as daddy long legs, observed in humid and shady areas. Many times females were observed carrying their egg sacs. Pisuiridae (3 species from 2 genera) or Nursery web spiders, carry their egg sacs by means of their jaws and pedipalps these spiders were observed at river site or near water bodies. Scytodidae (2 species from 1 genus) or spitting spiders, have six eyes arranged in three pairs, found under bark and leaf-litter. Sicariidae (1 species from 1 genus) observed in dense forest. Six-eyed, venomous spiders known for their allegedly necrotic bites. Sparasiidae (2 species from 1 genus) or Huntsman spiders found in humid places. Tetragnthidae $(7$ species from 2 genera) long-jawed orb weavers, mostly observed in vegetation near water bodies. Theridiidae (3 species from 3 genera) or comb-footed spiders, these were collected from on the ground, on plants, in burrows and caves, often webs were found in dark. Theridiosomatidae found in damp habitats, among low-growing vegetation. Thomosidae (11 species from 6 genera) or crab spider / flower crab spider, were observed Wandering on plant and ground, mainly on foliage, camouflages with surrounding. Uloboridae (3 species from 2 genera) cribellate orb weavers or hackled orb weavers. These are nonvenomous spiders. These were observed in dry as well as humid habitat on vegetation.

Spiders feeds on insects and other small arthropods, any specific selectivity was not observed in selection of food rather they feed on eggs, larvae of insects along with adults. Depending upon availability of food spiders population was observed varied. However spiders can remain starved for comparatively longer time. Diversity and abundance of spiders depends on population of insects. Diversity of insects is mostly determined by ecological conditions, flora and other environmental 
factors. Therefore spiders can be used as bio-indicator species of any ecosystem.

\section{REFERENCES}

Bastawade, D. B., 2004. Arachnid fauna of orders Araneae, Scorpionida and Solifugi from Melghat Tiger Reserve, Distt. Amravati, Maharashtra. Proceeding of Symposium on Three Decades of Project Tiger in Melghat. 8-9 0cto. 2004, 70-71.

Biswas, B. and K. Biswas, 2004. Araneae: Spiders. In: Fauna of Manipur, State Fauna Series 10, Zoological Survey of India: 25-46.

Barrion A.T. and J.A. Listinger 1995. Riceland spiders of south and southeast Asia. CAB international, Wallingford, England, $736 \mathrm{p}$.

Deshmukh U.S. and N M Raut (2014) Seasonal Diversity and Status of Spiders (Arachnida: Araneae) in Salbardi forest (Satpura Range), Maharashtra, India. Journal of Entomology and Zoology Studies.,2 (6): 278-281.

Gajbe, U. A. 1995a. Spiders Fauna of Conservation Areas: Fauna of Kanha Tiger Reserve, Madhya Pradesh. Zooological Survey of India, Publication: 27-30.

Gajbe, U. A. 1995b. Spiders, Fauna of Conservation Areas: Fauna of Indravati Tiger Reserve, Madhya Pradesh. Zoological Survey of India, Publication: 53-56.

Gajbe, U. A. (1999). Studies on some spiders of the family 0xyopidae (Araneae: Arachnida) from Rec. Zoological Survey of India 97(3): 31-79.

Gajbe, P. 2003. Checklists of Spiders (Arachnid; Araneae) of Madhya Pradesh and Chattisgarh. Zoos. Print Journal 18 (10): 1223-1226.

Hippargi R.V.; A.K. Bodkhe; M.P. Chikhale; G.B. Santape; R. M. Behere; P.M. Bolde,;S. Manthen; K.R. Rao and N.V. Shah. 2011b. Spider (Arachnida: Araneae) Families of Three Ecosystems of Maharashtra, India. E-International Scientific Research Journal Volume: 3 Issue:1, 2011
Hore, U. and V.P. Uniyal, 2008a. Use of Spiders (Araneae) as Indicator for Monitoring of Habitat Condition in Terai Conservation Area, India. Indian Forester Vol. 134, No. 10: 1371-1380.

Hore, U. and V.P. Uniyal, 2008 b. Diversity and composition of spider assemblages in five vegetation types of the Terai Conservation Area, India. J. Arachnol. 36: 251-258.

Hore, U. and V.P. Uniyal, 2008. Effect of prescribed fire on spider assemblage in Terai grasslands, India. Turkish Journal of Arachnology, Vol.1 (1): 15-36.

Manju Siliwal, B. Suresh and Bonny Pilo. 2003. Spiders of Purna wildlife Sanctuary, Dangs,Gujarat. Zoos. Print Journal 18 (11): $1259-1263$

Patel, B. H. 2003. Fauna of Protected Areas - A Preliminary list of Spiders with the descriptions of three new species from Parambikulum Wildlife sanctuary, Kerala. Zoos. PrintJournal 18 (10): $1207-1212$.

Platnick, N. I. (1989). Advances in Spider Taxonomy 19811987: A Supplement to Brignoli's A Catalog of the Araneae Described Between 1940 and 1981 (edited by P. Merrett). Manchester University Press, 673pp.

Platnick, N. I. (2014). Jonathan Amos Ancient arachnid walks again. BBC Retrieved 9 July 2014.

Sebastin P.A. and K.V. Peter (2009). The spider fauna of the irrigated rice ecosystem, in central Kerala, India. The journal of Arachnology , 33: 247-255.

Tikader, B.K. (1974) Gazetteer of India, Maharashtra state, General Series: Fauna, Chapter 4 -Spiders, 295-306.

Tikader, B.K. and Malhotra, M.S. (1980). Fauna of Indian Spider (Araneae) Vol. I, Thomicidae.1-225 PP.

Tikader, B. K. (1982a). Family Araneidae (Argiopidae), typical orbweavers. Fauna India (Araneae) 2: 1-293.

Tikader, B. K. (1982b). Family Gnaphosidae. Fauna India (Araneae) 2: 295-536.

Tikader, B.K. (1987). Handbook of Indian Spiders, Zoological Survey of India. Calcutta, India.251 PP. 